Jorge Andrés Muñoz Mendoza" Sandra María Sepúlveda Yelpo* " Carmen Lissette Veloso Ramos"

Universidad de Concepción Concepción, Chile

Recibido: 7 de noviembre de 2017 Concepto de evaluación: 15 de junio de 2018

Aprobado: 20 de junio de 2018

Artículo de investigación (C) 2018 Universidad Católica de Colombia. Facultad de Ciencias Económicas y Administrativas. Todos los derechos reservados

* M.A. in Economics, Assistant Professor, Universidad de Concepción, Los Ángeles, Chile; Email: jormunozm@udec.cl. https://orcid. org/0000-0002-775-5307.

** M.A. in Business Administration (MBA), Assistant Professor, Universidad de Concepción, Los Ángeles, Chile; Email: ssepulveday@udec.cl.https:// orcid.org/0000-0002-2614-7356.

*** M.A. in Business Administration (MBA), Professor, Universidad de Concepción, Los Ángeles, Chile; Email: carmenveloso@udec.cl. https://orcid. org/0000-0001-9390-9974.
Finanz. polit. econ., ISSN: 2248-6046, Vol. 10, N. ${ }^{\circ}$ 2, julio-diciembre, 2018, pp. 269-286

http://dx.doi.org/10.14718/revfinanzpolitecon.2018.10.2.2

\section{Effects of Corporate Policies and Governance Practices on Ownership Structure: Evidence from Chilean Firms*}

\section{ABSTRACT}

We analyze the effects of financing policies, dividends, and corporate governance on ownership structure in Chilean companies. We used a sample of 185 companies listed on the Santiago Stock Exchange that answered the NCG 341 survey on Corporate Governance Practices in 2013. The two-limit Tobit regression (TLTR) results show that debt and dividend policies exert a negative effect on controlling shareholder ownership and a positive effect on minority shareholder ownership. The results show that these policies facilitate control over corporate management determined by the interests of controlling shareholders, as well as protect minority shareholders' rights by complementing their monitoring role. Corporate governance practices have significant effects on the ownership structure of Chilean companies.

Keywords: Financing policy, dividend, corporate governance, ownership structure.

JEL code: G32, G35, G38.

Efectos de las políticas y prácticas de gobierno corporativo sobre la estructura de propiedad: evidencia de compañías chilenas

\section{RESUMEN}

Este artículo se propone analizar el impacto de las políticas de financiamiento, dividendos y gobierno corporativo sobre la estructura de propiedad en compañías chilenas. Se usó una muestra de 185 compañías listadas en la Bolsa de Comercio de Santiago, que contestaron la encuesta NCG 341 sobre Prácticas de Gobierno Corporativo en 2013. Los resultados de las regresiones Tobit de dos límites (TLTR) demuestran que las políticas de endeudamiento y de

The University of Concepción financially supported this research. Remaining errors are the sole responsibility of the authors. 
dividendos negativamente afectan la propiedad de los accionistas controladores y protegen los derechos de los accionistas minoritarios al complementar su rol de monitoreo. Las prácticas de gobierno corporativo tienen efectos significativos sobre la estructura de propiedad de las compañías chilenas.

Palabras clave: financiamiento, dividendos, gobierno corporativo, estructura de propiedad.

\section{Efeitos das políticas e práticas de governo corporativo sobre a estrutura de propriedade: evidência de companhias chilenas}

\section{RESUMO}

Este artigo propõe a analisar o impacto das políticas de financiamento, dividendos e governo corporativo sobre a estrutura de propriedade em companhias chilenas. Utiliza-se uma amostra de 185 companhias relacionadas na Bolsa de Comércio de Santiago que responderam à pesquisa NCG 341 sobre Práticas de Governo Corporativo em 2013. Os resultados das regressões Tobit de dois limites (TLTR) demonstram que as políticas de endividamento e de dividendos afetam negativamente a propriedade dos acionistas controladores e protegem os direitos dos acionistas minoritários ao complementar seu papel de monitoramento. As práticas de governo corporativo têm efeitos significativos sobre a estrutura de propriedade das companhias chilenas.

Palavras-chave: financiamento, dividendos, governo corporativo, estrutura de propriedade. 


\section{INTRODUCTION}

Corporate ownership structure has been at the center of analysis and discussion in the last decades due to the globalization of international markets. Literature concludes that factors such as debt, dividends, growth opportunities, firm profitability, among many others, can explain the ownership structure of firms (Jensen \& Meckling, 1976; Thomsen \& Pedersen, 1996; Baek et al., 2006; Céspedes et al., 2010). Whatever is the case, the way in which companies form their corporate ownership may have direct implications on the control of decisions and relationships between shareholders.

The characteristics of the institutional environment of countries could also be relevant to corporate ownership structure (La Porta et al., 1997; Mak \& Li, 2001; Weiss \& Richter, 2010; Hatem, 2014). In this sense, Latin American countries, and particularly Chile, have an institutional environment that is governed by French civil law. Low legal protection for investors, which is a characteristic of these countries, may lead them to concentrate corporate ownership as a way to monitor investments and to achieve a positive return on assets (Barclay \& Holderness, 1989; Shleifer \& Vishny, 1997; La Porta et al., 1998, 1999; Anderson \& Reeb, 2004). Thus, pyramidal ownership structures, which are highly concentrated and have a strong presence of business conglomerates, are recurrent in these countries.

This context provides a propitious space for wealth expropriation from minority shareholders (Johnson et al., 2000; Booth et al., 2001; Nenova, 2003; Silva et al., 2006; Santiago \& Brown, 2007). In Chile, during recent years, several events associated with bad corporate governance practices have highlighted not only the low legal protection of non-controlling investors, but also an economic deterioration due to discretionary decisions by controlling shareholders. For example, La Polar in 2011, the case of CMPC and PISA in 2015, SQM in 2015, Masvida en 2017, among others, are some cases of public interest and important judicial reaches. These cases had relevant effects for different stakeholders.
The above mentioned facts justify the establishment of different control means to mitigate potential wealth expropriation problems caused by ownership concentration in Chile. In this matter, financing and dividend policies could play a significant monitoring role on corporate management established by controlling shareholders. Several studies have corroborated this control role (Bae et al., 2002; Chu \& Cheah, 2004; Baek et al., 2006). In addition, Chile's entry into the Organization for Economic Cooperation and Development (OECD) in 2010 has called into question the policies of corporate governance developed by Chilean companies and their degree of compliance with governance practices recommended by the international body. This fact has not yet been studied in Chile, nor its role on ownership structure.

We analyze the effects of financing, dividend, and corporate governance policies on the ownership structure of Chilean companies. Our research contributes empirical evidence on Chile and other emerging countries governed by French civil law in two aspects. First, we analyze the potential nonlinear effects of financing and dividend policies on ownership structure. Although many studies support that both policies have a substitute control effect in relation to controlling shareholder ownership and a complementary control effect on minority shareholder ownership, nonlinearity would suggest that these effects are not persistent. Second, we study the impact of corporate governance policies suggested by the OECD on ownership structure. We seek to measure whether these governance practices have the capacity to mitigate or exacerbate wealth expropriation.

In order to comply with these objectives, we used a cross-sectional sample of 185 companies listed on the Santiago Stock Exchange in 2013, which answered the survey of the Standard of General Character 341 (Encuesta Norma de Carácter General 341, henceforth NCG 341), prepared by the Superintendence of Securities and Insurance (SSI). Results indicate that debt and dividend policies exert a negative impact on controlling shareholder ownership and a positive impact on minority 
shareholder ownership. Both policies contribute to mitigating wealth expropriation, although their nonmonotonic effect indicates that such an impact is not persistent. Thus, in case of higher debt levels and higher dividend rates, it is possible to observe a higher degree of ownership concentration, which transfers the financial risk of debt to minority shareholders, reducing their participation. The corporate governance practices outlined by the OECD have a similar effect.

After this introduction, Section 2 reviews literature concerning the effects of financing, dividends, and corporate governance policies on ownership structure, and presents the hypotheses of this work. Section 3 describes the variables and methods used in this article. Section 4 presents the results obtained, while Section 5 culminates with the conclusions and extensions of this study.

\section{THEORETICAL FRAMEWORK AND HYPOTHESIS}

Ownership structure in Latin America is characterized by high concentration, pyramidal form, and a significant presence of business conglomerates (Lins, 2003; Lefort, 2005). Leal and De Oliveira (2002) point out that the five largest shareholders of Brazilian firms make up, on average, $58 \%$ of ownership, while Lefort and Walker (2000) indicate that this figure is approximately $80 \%$ in Chile. Apreda (2000) and De Michele (2002) point out that in the 20 largest Argentinean companies, controllers own almost two thirds of market capital.

Particularly, in Chile, this business context, together with low levels of legal protection for investors, has led to wealth expropriation from minority shareholders. Thus, monitoring exercised by financing, dividend, and corporate governance policies may be relevant to ownership structure.

\section{Effects of financing policy on ownership structure}

Financing policy may be relevant to corporate ownership structure, although international evidence has shown a lack of consensus regarding the effects of debt decisions on corporate ownership.

Some studies claim that corporate debt levels have a negative impact on ownership concentration. In this line, the seminal study by Jensen and Meckling (1976) points out that a higher level of corporate debt is associated with a more diluted (less concentrated) ownership structure. The authors suggest that debt could have a monitoring effect on company management, which would replace the controlling role typically exercised by majority owners. Other works, such as those by Leland and Pyle (1977), Diamond (1984), and Demsetz and Lehn (1985), reaffirm that debt reduces agency costs caused by the dilution of ownership due to control effects on discretional decisions made by corporate governance. In this context, Demsetz and Lehn (1985) add that when ownership is diluted, debt issuance contributes to reducing wealth expropriation, in positive association with non-controlling shareholder ownership.

There is also evidence supporting the described results in emerging markets. Du and Dai (2005) analyzed ownership structure in a sample of firms in East Asia. Their results indicate that firms with less concentrated ownership structures use debt as a means to avoid losing corporate control. In Latin America, Booth et al. (2001) add that firms use debt less than other markets with similar structural characteristics. According to this, debt has a greater control effect. Chong and Lopez de Silanes (2007) and Céspedes et al. (2010) argue that debt significantly reduces ownership concentration and increases minority shareholders ownership, mitigating wealth expropriation. This leads us to the following hypothesis:

H1: Debt has a negative (positive) effect on majority (minority) shareholder ownership.

Other part of the international evidence describes a positive effect of debt on ownership concentration. Bae et al. (2002) and Baek et al. (2006) point out that this positive relationship suggests that debt exercises a complementary monitoring role in relation to ownership concentration. 
This fact facilitates wealth expropriation from minority shareholders. Hatem (2014) supports this result in a study comparing German companies (civil law) and U.K. companies (common law). In Chile, Morales et al. (2013) have also corroborated this result in a study that used 67 companies listed on the Santiago Stock Exchange between 1990 and 2007. They add that this complementary relationship is an indicator that Chilean companies have better access to bank financing and bond markets, so it is not necessary to distribute capital to obtain funds. In any case, higher debt would have a negative effect on minority shareholder ownership, as it would transfer the financial risk of higher debt. Céspedes et al. (2010) conclude that these findings could be explained by a non-linear relationship between debt levels and ownership structure. In Chile, this fact has not been investigated so far, leading us to formulate the following hypothesis:

H2: Debt has a non-linear effect on ownership structure.

\section{The effect of dividend policy on ownership structure}

Dividend policy can also become a determinant of ownership structure. A relevant part of international studies indicate that dividends are negatively related to ownership concentration and positively to ownership dilution. Rozeff (1982) proposed that ownership concentration is associated with lower dividends; thus, as ownership structure becomes more diluted, firms' dividends should increase. Agency theory holds that dividends would help mitigate wealth expropriation derived from a conflict of interests between minority and majority shareholders (Shleifer \& Vishny 1997; La Porta et al., 1999). The relationship described transforms dividend policy into a means of control, which replaces the monitoring role exercised by ownership concentration over agency conflict. A wide range of literature has documented and sustained this result (Faccio \& Lang,
2001; Mancinelli \& Aydin, 2006; Setia-Atmaja, 2009; López-Iturriaga \& Lima, 2014; Mori \& Ikeda, 2015). Another aspect that complements this analysis is institutional environment. In countries governed by civil law, low legal protection for investors could also be replaced by higher dividend rates, which would reinforce a trade-off with ownership concentration. In general, research in Chile has evidenced that dividends contribute to controlling agency costs (Maquieira \& Danús, 1998; Maquieira \& Moncayo, 2004). More recently, Morales et al. (2013) have demonstrated that dividends are negatively related to controlling shareholder ownership and positively to the second largest shareholder, leading us to the following hypothesis:

H3: Dividend policy has a negative (positive) effect on majority (minority) shareholder ownership.

However, there are studies that oppose the traditional view of negatively relating dividends to ownership concentration. Faccio et al. (2001), in a study comparing firms in Asia and Europe, found evidence that more concentrated ownership structures pay higher dividends. In line with this result, Ramli (2010) adds that ownership concentration is a means of protection for investors, which complements dividend policy. Burkart and Panunzi (2006) point out that this relation occurs when greater legal protection for investors proposes a means of substitute monitoring, which correlates positively with ownership concentration. If this is the case, concentrated pyramidal ownership structures with high family ownership may be related to higher dividends (Bradford et al., 2013). Roy (2015) adds that this context, together with the participation of family shareholders in minority shareholder ownership, would be another argument for a positive relationship with dividend policy. Furthermore, he states that such a relationship would become negative for non-family minority shareholders. Such is the case in Chile, where, in addition, there is a legal minimum payment of $30 \%$, which could alter the 
effects of dividend policy on ownership structure. The collusion of these effects could be due to the fact that this relationship is not linear, leading us to formulate the following hypothesis:

H4: Dividend policy has a non-linear effect on ownership structure.

\section{Effects of corporate governance on ownership structure}

Another issue that has gained increasing ground in discussions regarding corporate ownership structure is corporate governance policy. Fama and Jensen (1983a, 1983b) argue that the basis of good corporate governance is centered on relationships between control and business management. At this point, relationships between control and minority shareholders may be affected by corporate governance policies, since these investors perceive it as a mutually protective medium. Shleifer and Vishny (1997) and Klapper and Love (2004) corroborate this view and add that corporate governance performance is positively related to investor protection measures.

In countries governed by civil law, where protection mechanisms are poor and ownership concentration is higher, corporate governance roles become more relevant. This scenario provides a propitious space for majority shareholders to expropriate wealth from minority shareholders (Renders \& Gaeremynck, 2012). However, Hung (1998) points out that corporate governance is constituted to align the interests of all internal and external agents with company objectives. In this sense, mitigating conflicts of interest, wealth expropriation, and ensuring firm performance would be the main functions of corporate governance. These corporate governance practices could lead firms to a state of greater financial performance consistent with the shareholder wealth maximization objective (Zahra \& Pearce, 1989; Brown \& Caylor, 2004). These facts are directly related to controlling and minority shareholders ownership.
There is little evidence in this regard in Chile. Works such as those by Lefort and Walker (2007) do nothing more than suggest that discrepancies between shareholders have implications on the stock market. However, no study analyzes the effect of corporate governance mechanism on ownership structure in Chilean companies. In addition, during 2010, Chile joined the OECD. For Chile, this meant fulfilling certain economic, financial, and public policy objectives. With regard to the corporate governance of firms, agency theory suggests that firms develop certain governance practices to benefit various investors and other stakeholders. The SSI developed the NCG 341 survey in order to assess the degree of compliance of governance practices with those recommended by this institution. The effect of these policies on the configuration of the ownership structure in Chilean companies has not been investigated yet, and, for this reason, we formulated the following hypothesis:

H5: Corporate governance policies have a positive effect on majority and minority shareholder ownership.

\section{DATA AND METHODS}

\section{Research data}

The data used in this investigation corresponds to 185 companies listed on the Santiago Stock Exchange for 2013, which answered the NCG 341 survey. Pertinent information to this company sample was extracted from three sources of information: (a) results of the NCG 341 survey obtained from the SSI, (b) the 2013 financial statements compiled from the Economática ${ }^{\circledR}$ database, and (c) dividends collected from annual reports and minutes of ordinary shareholder meetings. Table 1 presents the study variables.

The research-dependent variable is ownership structure, which is measured through 
two proxies. The SHARE1 variable measures controller shareholder ownership as a way of calculating ownership concentration, while SHARE5 measures minority shareholder ownership, and therefore ownership structure dilution. These measures follow the suggestions of various studies (Santiago \& Brown, 2007; Morales et al., 2013).

Corporate governance variables are measured as indicated in Table 1 and represent governance postulates specified by Fama and Jensen (1983a, 1983b). It is important to note that the NCG 341 survey applied by the SSI aims to establish a dissemination mechanism regarding governance standards in Chilean corporations and their degree of compliance with the four principles of good corporate governance practices recommended by the OECD. The survey, grouped into four categories, contains 19 questions of a binary nature, which were answered by the boards of the 185 companies. These four categories are based on the principles recommended by the OECD: (a) functioning of the board, (b) relationship with stakeholders, (c) executive compensation, and (d) internal control policies.

Debt-to-equity ratio (LEV) and dividend payment rate (DIV) are variables associated with corporate policies. According to several studies, LEV is used as a means of control associated with ownership structure. This control role could be substitute or complementary (Demsetz \& Lehn, 1985; Booth et al., 2001; Bae et al., 2002). Dividend payment rate (DIV) is used as a form of cash flow distribution when there are conflicts of interest between managers and different shareholders (Chu \& Cheah, 2004; Morales et al., 2013).

Other control variables are used in line with other studies. QTOB measures growth opportunities

Table 1.

Study variables

\begin{tabular}{|c|c|c|}
\hline & Variables & Definition \\
\hline \multicolumn{3}{|c|}{ A. Dependent variables } \\
\hline SHARE1 & Controlling shareholder ownership & Majority shareholder percentage of shares \\
\hline SHARE5 & Fifth-largest shareholder ownership & Fifth largest shareholder percentage of shares \\
\hline \multicolumn{3}{|c|}{ B. Characteristics of corporate governance } \\
\hline GP & Good practices & Dummy equal to 1 if it meets more than two categories \\
\hline NCAT & Number of categories met & Number of categories met by the firm \\
\hline BOARD & Functioning of the board & Dummy is 1 if firms meet this item by over $50 \%$ \\
\hline STHOLD & Relationship with stakeholders & Dummy is 1 if firms meet this item by over $50 \%$ \\
\hline EXECP & Executive compensation & Dummy is 1 if firms meet this item by over $50 \%$ \\
\hline INCONT & Internal control policy & Dummy is 1 if firms meet this item by over $50 \%$ \\
\hline \multicolumn{3}{|c|}{ C. Corporate policies } \\
\hline LEV & Financing policy & Debt-to-equity ratio \\
\hline DIV & Dividend policy & Dividend payment rate to shareholders \\
\hline \multicolumn{3}{|c|}{ D. Other control variables } \\
\hline QTOB & Tobin's Q & Market-to-book ratio \\
\hline SIZE & Firm size & Natural logarithm of total assets \\
\hline ROA & Return on assets & Net income to total assets ratio \\
\hline ACOST & Asset costs & Operating expense to net sales ratio \\
\hline AGE & Age of the firm & Years of company legal existence \\
\hline FEXP & Financial expenses & Operating income to financial expenses ratio \\
\hline
\end{tabular}

Source: Authors' elaboration based on Economática and SSI. 
Jorge Andrés Muñoz Mendoza • Sandra María Sepúlveda Yelpo • Carmen Lissette Veloso Ramos

through the Tobin's Q (La Porta et al., 2002), SIZE represents firm size (Thomsen \& Pedersen, 1996; Pedersen \& Thomsen, 1997; Pindado \& De la Torre, 2006), ROA is the return on assets (Krivogorsky, 2006), ACOST indicates agency costs (Ang et al., 2000), AGE is the firm's age (Boeker, 1989; Chibber \& Majumdar, 1999; Claessens et al., 2000), and FEXP indicates financial expenses coverage ratio.

\section{Econometric method}

A two-limit Tobit regression (TLTR) model is used to determine the effect of debt, dividend, and corporate governance policies on ownership structure. The specified model is:

$O S_{i}=\beta_{0}+\beta_{1} C G_{i}+\beta_{2} L_{E V}+\beta_{3} L_{E V}{ }^{2}+\beta_{4} D_{I V}+\beta_{5} D V_{i}^{2}$

$+\beta_{6} \mathrm{QTOB}_{i}+\beta_{7} \mathrm{ROA}_{i}+\beta_{8} \mathrm{ACOST}_{i}+\beta_{9} \mathrm{FEXP}_{\mathrm{i}}+$

$\beta_{10}$ SIZE $_{i}+\beta_{11} A G E_{i}+\delta_{0} D$ Sector $+\varepsilon_{i}$

The variable $O S_{i}$ represents ownership structure measured by controlling shareholder ownership (SHARE1) and minority shareholder ownership (SHARE5). According to Table 1, CG represents different dimensions of corporate governance developed by Chilean companies. $L E V_{i}$ is the debt-to-equity ratio, with which the effect of the financing policy is quantified, $L E V_{i}^{2}$ captures the potential non-monotonic effects of the financing policy on ownership structure, $D I V_{i}$ is the dividend payment rate, and $D I V_{i}^{2}$ quantifies the non-linear effect of this policy.

The model also includes controls through certain structural characteristics of the firms. Variables such as future growth opportunities measured by the Tobin's $Q\left(Q T O B_{i}\right)$, return on assets $\left(R O A_{i}\right)$, agency costs $\left(A C O S T_{i}\right)$, financial solvency measured by the financial expenses coverage ratio $\left(F E X P_{i}\right)$, company size $\left(S I Z E_{i}\right)$ and their age $\left(A G E_{i}\right)$ represent these control variables. The model also includes dummy variables by economic sectors to control company differences (DSector). Finally, $\varepsilon_{\mathrm{i}}$ is the random residual of the model.

\section{RESULT ANALYSIS}

\section{Sample description}

Table 2 shows the descriptive statistics and correlations of variables in relation to ownership structure measurements.

Ownership structure variables showed large differences between controlling shareholder ownership and the fifth-largest shareholder ownership. The latter was employed as an approximation to the position of minority shareholders. While controllers concentrate $49.86 \%$ of ownership, minority shareholders own only 3.39\%. In Latin American countries like Chile, such structures are common. The institutional environment based on French civil law, which is a characteristic of these countries, favors ownership concentration for controlling shareholders, as well as wealth expropriation.

Variables characterizing corporate governance were developed through the NCG 341 survey. In general terms, it was observed that companies meet approximately two out of four corporate governance categories recommended by the OECD. More frequently used governance practices are internal control policies (INCONT), carried out by $54.27 \%$ of companies, and functioning of the board (BOARD), carried out by $52.34 \%$ of companies. Executive compensation policies (EXECP) were carried out by $51.44 \%$ of companies, and relationship with stakeholders (STHOLD) by $35.12 \%$, which is the least frequently used policy. This last governance practice includes relationships maintained by companies with different interest groups, such as bondholders and minority shareholders, among others. Lower degrees of compliance demonstrated in this variable reveal companies' lower concern for the rights of non-controlling investors. This policy is negatively and significantly correlated with controlling shareholder ownership, but positively with minority shareholder ownership.

LEV, which represents financing policy, was measured by the debt-to-equity ratio, which is 1.88 on average. This figure indicates that, on average, 
Table 2.

Descriptive statistics and correlations

\begin{tabular}{|c|c|c|c|c|c|}
\hline & Variables & Mean & S.D. & \multicolumn{2}{|c|}{ Correlation } \\
\hline \multicolumn{6}{|c|}{ A. Dependent variables } \\
\hline SHARE1 & Controlling shareholder ownership (\%) & 49.86 & 82.37 & $1.00 * * *$ & $-0.24 * * *$ \\
\hline SHARE5 & Fifth-largest shareholder ownership (\%) & 3.39 & 2.49 & $-0.24^{* * *}$ & $1.00^{* * *}$ \\
\hline \multicolumn{6}{|c|}{ B. Corporate governance characteristics } \\
\hline GP & Good practices & 56.23 & 25.41 & $0.12^{* * *}$ & $0.23 * * *$ \\
\hline NCAT & Number of categories met & 1.92 & 1.44 & $0.05^{* * *}$ & $0.14^{* * *}$ \\
\hline BOARD & Functioning of the board (\% of firms) & 52.34 & 50.45 & $0.22 * * *$ & $0.17 * * *$ \\
\hline STHOLD & Stakeholder relations (\% of firms) & 35.12 & 48.23 & $-0.16^{* * *}$ & $0.21 * * *$ \\
\hline EXECP & Executive compensation (\% of firms) & 51.44 & 50.15 & $-0.11 * * *$ & $0.15^{* * *}$ \\
\hline INCONT & Internal control policies (\% of firms) & 54.27 & 50.32 & $0.05^{* * *}$ & $0.27 * * *$ \\
\hline \multicolumn{6}{|c|}{ C. Corporate policies } \\
\hline LEV & Financing policy & 1.88 & 7.18 & $-0.21 * * *$ & $0.15^{* * *}$ \\
\hline DIV & Dividend policy & 42.74 & 29.93 & $-0.29 * * *$ & $0.18^{* * *}$ \\
\hline \multicolumn{6}{|c|}{ D. Other control variables } \\
\hline QTOB & Tobin's Q & 1.21 & 1.86 & $0.17^{* * *}$ & $0.09 * * *$ \\
\hline SIZE & Firm size (MM\$) & $1,198,639$ & $3,152,101$ & $-0.06 * * *$ & $0.09 * * *$ \\
\hline ROA & Return on assets (\%) & 4.27 & 11.80 & $0.14^{* * *}$ & $0.17 * * *$ \\
\hline ACOST & Agency costs (\%) & 18.98 & 47.37 & $-0.18 * * *$ & $0.09 * * *$ \\
\hline AGE & Age of the firm (years) & 39.98 & 31.32 & $0.09 * * *$ & $0.03^{* * *}$ \\
\hline FEXP & Financial expenses (factors) & 6.44 & 13.57 & $0.11 * * *$ & $0.24^{* * *}$ \\
\hline
\end{tabular}

Superscripts ***,**,* indicate statistical significance at 1, 5, and 10 percent, respectively.

Source: Authors' elaboration.

sample companies were financed with $65.28 \%$ debt and $34.72 \%$ equity. On the other hand, dividend policy rates (DIV) show that, on average, $42.74 \%$ of the profit was distributed in payments to shareholders (amount calculated only for paying companies). In any case, it highlights the fact that both policies are negatively correlated with controlling shareholder ownership and positively with minority shareholder ownership. Evidence indicates that debt and dividends are substitute means for monitoring in relation to ownership concentration, and they promote minority investor controlling rights.

Regarding the structural characteristics of the sample companies, average growth opportunities (QTOB) were 1.21 , accompanied by a $4.27 \%$ return of assets (ROA) and a 6.44 average financial expenses ratio (FEXP). The average age (AGE) of companies was almost 40 years, with agency costs (ACOST) equivalent to $18.98 \%$ of sales.

\section{Effects of financing, dividend, and corporate governance policies on ownership structure}

This section analyzes the regression indicated in [1] to verify the effects of financing, dividend, and corporate governance policies. Table 3 shows the results of the regression applied on the dependent variable SHARE1, which is ownership concentration indicated by controlling shareholder participation.

Coefficients confirmed the results obtained by previous studies for certain control variables. Company age (AGE) had no significant effect on ownership concentration. Growth opportunities (QTOB) had a positive and significant effect on ownership concentration, which is consistent with La Porta et al. (2002). Greater opportunities for future growth constitute a positive indicator of the economic potential 
of the company, leading shareholders to increase their participation as a way to obtain a fraction of this growth. Likewise, return on assets (ROA) and financial expenses (FEXP) had a positive effect on ownership concentration (Krivogorsky, 2006).

Agency costs (ACOST) had an expected negative effect. In line with Berle and Means (1932), Jensen and Meckling (1976), and Jensen (1986), higher agency costs were associated with less participation by controlling shareholders. The potential loss of corporate control and the generation of additional expenses were related to ownership dilution and the weakening of monitoring mechanisms by controlling shareholders.

Firm size (SIZE) had a negative effect on controlling shareholder ownership. This result reaffirms that larger firms are more expensive to manage for controllers due to structural and organizational complexity (Demsetz \& Lehn, 1985; Thomsen \& Pedersen, 1996; Pedersen \& Thomsen, 1997; Pindado \& De la Torre, 2012). In this sense, the negative effects described are synonymous with lower degrees of control as companies increase in size.

There is a negative and significant effect on controlling shareholder ownership regarding financing policy (LEV). This result supports the $\mathrm{H} 1$ hypothesis and suggests that both debt and ownership concentration in majority shareholders are substitute means of control (Jensen \& Meckling, 1976; Diamond, 1984; Chong \& Lopez de Silanes, 2007; Céspedes et al., 2010). In this way, debt can externally substitute the monitoring role when ownership is partially diluted. This negative effect could be common in Latin American countries like Chile, since debt is less used than equity as a source of financing (Booth et al., 2001). On the other hand, debt effects are non-linear and have a U-shape, a fact that supports the $\mathrm{H} 2$ hypothesis. This result shows that debt acts as a substitute control for ownership concentration only when debt is low, and it is complementary when leverage is high. This is in line with Du and Dai (2005) and Céspedes et al. (2010), who suggest that complementary relationships between majority shareholder ownership and debt are due to the need to not lose corporate control.

Dividend policy (DIV) also has a negative and non-linear (U-shaped) effect on controlling shareholder ownership. These results support the $\mathrm{H} 3$ and $\mathrm{H} 4$ hypotheses, respectively. The result agrees with previous studies and points out that dividends are initially a means of proportional control in the face of loss of control by majority shareholders, dilution of ownership, and mitigation of agency conflicts between shareholders (Rozeff, 1982; Faccio \& Lang, 2001; Mancinelli \& Aydin, 2006; Setia-Atmaja, 2009; Pindado et al., 2012; López-Iturriaga \& Lima, 2014; Mori \& Ikeda, 2015). Dividend payments could reduce the future growth potential of firms and shareholder incentives to raise their share of ownership (Chu \& Cheah, 2004). However, Lang and Litzenberger (1989) and Yoon and Starks (1995) indicate that raising dividends emits a positive signal regarding future performance, which in turn would encourage greater participation by controllers. Both results would be supported by the non-linear effect of dividend policy.

Finally, corporate governance variables presented mixed results. On the one hand, the majority development of good corporate governance practices (GP), the functioning of the board (BOARD), and internal control policies (INCONT) are variables that have a positive and significant impact on controlling shareholder ownership. These results validate the $\mathrm{H} 5$ hypothesis. The effects of these variables indicate that ownership concentration is based on the strengthening of control mechanisms and a better decision-making process (Fama \& Jensen, 1983a, 1983b; Zahra \& Pearce, 1989; Brown \& Caylor, 2004).

On the other hand, policies that foster relationships with various stakeholders (STHOLD), as well as executive compensation (EXECP) have a significant negative effect, which goes against the H5 hypothesis. In Chile, a country characterized by using French civil law, the low protection of minority shareholders and other stakeholders would favor ownership concentration over controlling shareholders. This would even facilitate wealth expropriation 
Table 3.

Two-limit Tobit regression for controlling shareholder ownership, marginal effects

\begin{tabular}{|c|c|c|c|c|c|c|c|}
\hline \multirow[t]{2}{*}{ Variables } & \multicolumn{7}{|c|}{$\begin{array}{c}\text { Dependent variable: Controlling shareholder ownership (SHARE1) measured as the percentage of stocks held } \\
\text { by the controlling shareholder }\end{array}$} \\
\hline & (1) & $(2)$ & (3) & $(4)$ & (5) & (6) & (7) \\
\hline \multicolumn{8}{|c|}{ A. Corporate governance characteristics } \\
\hline \multirow[t]{2}{*}{ GP } & 0.183 & & & & & & 0.173 \\
\hline & $(1.97)^{* *}$ & & & & & & $(1.77)^{*}$ \\
\hline \multirow[t]{2}{*}{ NCAT } & & 0.008 & & & & & 0.002 \\
\hline & & $(1.53)$ & & & & & $(0.93)$ \\
\hline \multirow[t]{2}{*}{ BOARD } & & & 0.123 & & & & 0.138 \\
\hline & & & $(2.77)^{* * *}$ & & & & $(2.92)^{* * *}$ \\
\hline \multirow[t]{2}{*}{ STHOLD } & & & & -0.149 & & & -0.156 \\
\hline & & & & $(-1.97)^{* *}$ & & & $(-2.01)^{* *}$ \\
\hline \multirow[t]{2}{*}{ EXECP } & & & & & -0.103 & & -0.074 \\
\hline & & & & & $(-1.75)^{*}$ & & $(-1.57)$ \\
\hline \multirow[t]{2}{*}{ INCONT } & & & & & & 0.097 & 0.104 \\
\hline & & & & & & $(1.69)^{*}$ & $(1.75)^{*}$ \\
\hline \multicolumn{8}{|c|}{ B. Corporate policies } \\
\hline \multirow[t]{2}{*}{ LEV } & -0.968 & -1.023 & -0.945 & -0.993 & -1.105 & -1.003 & -0.952 \\
\hline & $(-3.22)^{* * *}$ & $(-2.99)^{* * *}$ & $(-2.51)^{* *}$ & $(-2.74)^{* * *}$ & $(-3.03)^{* * *}$ & $(-3.37)^{* * *}$ & $(-3.07)^{* * *}$ \\
\hline \multirow[t]{2}{*}{ LEV2 } & 0.334 & 0.294 & 0.302 & 0.359 & 0.316 & 0.331 & 0.299 \\
\hline & $(2.91)^{* * *}$ & $(2.12)^{* *}$ & $(2.54)^{* *}$ & $(3.04)^{* * *}$ & $(2.95)^{* * *}$ & $(2.67)^{* * *}$ & $(3.11)^{* * *}$ \\
\hline \multirow[t]{2}{*}{ DIV } & -0.036 & -0.043 & -0.039 & -0.045 & -0.049 & -0.042 & -0.044 \\
\hline & $(-2.26)^{* *}$ & $(-2.59)^{* * *}$ & $(-2.48)^{* *}$ & $(-2.66)^{* * *}$ & $(-2.89)^{* * *}$ & $(-2.47)^{* *}$ & $(-2.61)^{* * *}$ \\
\hline \multirow[t]{2}{*}{ DIV2 } & 0.019 & 0.026 & 0.021 & 0.025 & 0.028 & 0.024 & 0.023 \\
\hline & $(2.55)^{* * *}$ & $(2.87)^{* * *}$ & $(2.33)^{* *}$ & $(2.52)^{* *}$ & $(2.61)^{* * *}$ & $(3.03)^{* * *}$ & $(2.34)^{* *}$ \\
\hline \multicolumn{8}{|c|}{ C. Other control variables } \\
\hline \multirow[t]{2}{*}{ QTOB } & 2.961 & 2.579 & 2.985 & 3.002 & 2.741 & 2.904 & 2.654 \\
\hline & $(2.33)^{* *}$ & $(2.41)^{* *}$ & $(2.57)^{* *}$ & $(2.79)^{* * *}$ & $(2.59)^{* * *}$ & $(2.77)^{* * *}$ & $(2.37)^{* *}$ \\
\hline \multirow[t]{2}{*}{ ROA } & 0.056 & 0.061 & 0.057 & 0.055 & 0.059 & 0.051 & 0.060 \\
\hline & $(1.99)^{* *}$ & $(2.19)^{*}$ & $(2.01)^{* *}$ & $(2.22)^{* *}$ & $(1.93)^{*}$ & $(1.77)^{*}$ & $(1.97)^{* *}$ \\
\hline \multirow[t]{2}{*}{ ACOST } & -0.225 & -0.268 & -0.218 & -0.237 & -0.291 & -0.283 & -0.201 \\
\hline & $(-1.29)$ & $(-1.86)^{*}$ & $(-1.54)$ & $(-1.61)$ & $(-1.77)^{*}$ & $(-1.91)^{*}$ & $(-1.59)^{*}$ \\
\hline \multirow[t]{2}{*}{ FEXP } & 0.121 & 0.137 & 0.127 & 0.142 & 0.139 & 0.123 & 0.133 \\
\hline & $(2.66)^{* * *}$ & $(2.52)^{* *}$ & $(2.48)^{* *}$ & $(2.85)^{* * *}$ & $(2.37)^{* *}$ & $(2.61)^{* * *}$ & $(2.79) * * *$ \\
\hline \multirow[t]{2}{*}{ SIZE } & -0.004 & -0.003 & -0.002 & -0.002 & -0.004 & -0.005 & -0.003 \\
\hline & $(-2.31)^{* *}$ & $(-2.03)^{* *}$ & $(-2.22)^{* *}$ & $(-2.15)^{* *}$ & $(-2.48)^{* *}$ & $(-2.32)^{* *}$ & $(-2.58)^{* * *}$ \\
\hline \multirow[t]{2}{*}{ AGE } & 0.001 & 0.002 & 0.001 & 0.003 & 0.001 & 0.001 & 0.002 \\
\hline & $(0.89)$ & $(0.77)$ & $(0.81)$ & $(0.93)$ & $(0.69)$ & $(0.75)$ & $(0.67)$ \\
\hline Dummy sector & Yes & Yes & Yes & Yes & Yes & Yes & Yes \\
\hline Pseudo R2 & 0.45 & 0.44 & 0.46 & 0.42 & 0.42 & 0.44 & 0.46 \\
\hline Observations & 185 & 185 & 185 & 185 & 185 & 185 & 185 \\
\hline Wald & $(44.57)^{* * *}$ & $(43.98)^{* * *}$ & $(45.01)^{* * *}$ & $(44.32)^{* * *}$ & $(42.06)^{* * *}$ & $(43.92)^{* * *}$ & $(47.18)^{* * *}$ \\
\hline
\end{tabular}

Superscripts ***,**,* indicate statistical significance at 1, 5, and 10 percent, respectively.

Source: Authors' elaboration.

from various stakeholders and designation of managers who are usually guided by the economic interests of controllers.
Table 4 shows regression results applied to the dependent variable SHARE5 (minority shareholder ownership). Results were similar to those obtained in Table 3 for some control variables. 
Such is the case of company returns on assets (ROA), financial expenses (FEXP), and firm age (AGE). In addition, the variable that quantifies growth opportunities (QTOB) does not have a significant effect on minority shareholder ownership.

Agency costs (ACOST) had a direct and statistically significant effect on minority shareholder ownership. This impact reflects that these shareholders increase ownership interest as a means of control to monitor corporate management, thus preventing wealth expropriation executed by controlling shareholders. On the other hand, firm size (SIZE) had the expected positive effect, showing that a larger sized company is associated with the distribution of share capital.

Corporate policies have significant effects on minority shareholder ownership. Company debt (LEV) has a positive and non-linear effect, which supports the $\mathrm{H} 1$ and $\mathrm{H} 2$ hypotheses, respectively. This finding demonstrates that debt and minority shareholder ownership are complementary means of control over corporate governance and the discretionary decisions of controlling shareholders (Bae et al., 2002; Baek et al., 2006). However, nonlinearity suggests that complementary debt control decreases with higher leverage, indicating a potential free rider problem in marginal debt monitoring.

Like capital structure, dividend policy (DIV) also had a positive and non-linear effect on minority shareholder ownership. This result confirms hypotheses $\mathrm{H} 3$ and H4. According to Rozeff (1982), dividends allow the distribution of cash flows to minority shareholders to compensate them for potential conflicts of interest with controlling shareholders. However, this effect marginally decreases with increasing dividends. In fact, maximizing equation [1] with respect to dividends in each estimate indicated by Table 4 shows that dividend rates that maximize minority shareholder ownership are equal to $88.64 \%$. Comparing this figure with the average sample dividend of $42.74 \%$, we observed that the direct effect of payment policy is broad.

Variables that measure corporate governance policies had a positive and significant impact, except in the case of executive compensation policy (EXECP). These results corroborate the $\mathrm{H} 5$ hypothesis and demonstrate that as firms align with the OECD corporate governance recommendations, minority investor shares increase, mitigating thus

Table 4.

Two-limit Tobit regression for minority shareholder ownership, marginal effects

\begin{tabular}{|c|c|c|c|c|c|c|c|}
\hline \multirow[t]{2}{*}{ Variables } & \multicolumn{7}{|c|}{$\begin{array}{c}\text { Dependent variable: Minority shareholder ownership (SHARE5) measured as the percentage of stocks held by } \\
\text { the fifth largest shareholder }\end{array}$} \\
\hline & $(1)$ & $(2)$ & (3) & $(4)$ & $(5)$ & $(6)$ & $(7)$ \\
\hline \multicolumn{8}{|c|}{ A. Characteristics of corporate governance } \\
\hline \multirow[t]{2}{*}{ GP } & 0.284 & & & & & & 0.192 \\
\hline & $(2.32)^{* *}$ & & & & & & $(1.98)^{* *}$ \\
\hline \multirow[t]{2}{*}{ NCAT } & & 0.095 & & & & & 0.103 \\
\hline & & $(2.77)^{* * *}$ & & & & & $(2.22)^{* *}$ \\
\hline \multirow[t]{2}{*}{ BOARD } & & & 0.083 & & & & 0.096 \\
\hline & & & $(1.83)^{*}$ & & & & $(1.74)^{*}$ \\
\hline \multirow[t]{2}{*}{ STHOLD } & & & & 0.127 & & & 0.143 \\
\hline & & & & $(3.02)^{* * *}$ & & & $(3.65)^{* * *}$ \\
\hline \multirow[t]{2}{*}{ EXECP } & & & & & 0.011 & & 0.004 \\
\hline & & & & & $(0.94)$ & & $(0.43)$ \\
\hline \multirow[t]{2}{*}{ INCONT } & & & & & & 0.183 & 0.203 \\
\hline & & & & & & $(3.09)^{* * *}$ & $(2.86)^{* * *}$ \\
\hline \multicolumn{8}{|c|}{ B. Corporate policies } \\
\hline LEV & 1.587 & 1.476 & 1.637 & 1.558 & 1.461 & 1.701 & 1.527 \\
\hline
\end{tabular}




\begin{tabular}{|c|c|c|c|c|c|c|c|}
\hline \multirow[t]{2}{*}{ Variables } & \multicolumn{7}{|c|}{$\begin{array}{c}\text { Dependent variable: Minority shareholder ownership (SHARE5) measured as the percentage of stocks held by } \\
\text { the fifth largest shareholder }\end{array}$} \\
\hline & $(1)$ & $(2)$ & (3) & $(4)$ & $(5)$ & (6) & $(7)$ \\
\hline & $(4.58)^{* * *}$ & $(4.01)^{* * *}$ & $(4.77)^{* * *}$ & $(3.45)^{* * *}$ & $(3.85)^{* * *}$ & $(4.13)^{* * *}$ & $(3.64)^{* * *}$ \\
\hline \multirow[t]{2}{*}{ LEV2 } & -0.406 & -0.391 & -0.493 & -0.403 & -0.487 & -0.501 & -0.522 \\
\hline & $(-2.54)^{* *}$ & $(-2.47)^{* *}$ & $(-2.86)^{* * *}$ & $(-2.38)^{* *}$ & $(-2.59)^{* * *}$ & $(-2.91)^{* * *}$ & $(-2.32)^{* *}$ \\
\hline \multirow[t]{2}{*}{ DIV } & 0.083 & 0.092 & 0.088 & 0.084 & 0.079 & 0.082 & 0.086 \\
\hline & $(1.98)^{* *}$ & $(2.61)^{* * *}$ & $(2.46)^{\star *}$ & $(2.67)^{* * *}$ & $(2.50)^{* *}$ & $(2.25)^{* *}$ & $(2.39)^{* *}$ \\
\hline \multirow[t]{2}{*}{ DIV2 } & -0.044 & -0.051 & -0.049 & -0.046 & -0.047 & -0.053 & -0.046 \\
\hline & $(-3.01)^{* * *}$ & $(-2.89)^{* * *}$ & $(-2.95)^{* * *}$ & $(-3.21)^{* * *}$ & $(-3.07)^{* * *}$ & $(-3.01)^{* * *}$ & $(-2.84)^{* * *}$ \\
\hline \multicolumn{8}{|c|}{ C. Other control variables } \\
\hline \multirow[t]{2}{*}{ QTOB } & 1.056 & 1.027 & 0.982 & 1.001 & 1.203 & 0.919 & 1.199 \\
\hline & $(1.30)$ & $(1.33)$ & $(1.49)$ & $(1.38)$ & $(1.21)$ & $(1.17)$ & $(1.26)$ \\
\hline \multirow[t]{2}{*}{ ROA } & 0.123 & 0.105 & 0.118 & 0.113 & 0.127 & 0.121 & 0.115 \\
\hline & $(2.86)^{* * *}$ & $(2.94)^{* * *}$ & $(2.63)^{* * *}$ & $(2.84)^{* * *}$ & $(2.71)^{* * *}$ & $(2.80)^{* * *}$ & $(2.53)^{* *}$ \\
\hline \multirow[t]{2}{*}{ ACOST } & 0.329 & 0.357 & 0.318 & 0.326 & 0.332 & 0.339 & 0.347 \\
\hline & $(1.91)^{*}$ & $(2.03)^{* *}$ & $(1.68)^{*}$ & $(1.77)^{*}$ & $(2.03)^{* *}$ & $(2.11)^{* *}$ & $(2.16)^{* *}$ \\
\hline \multirow[t]{2}{*}{ FEXP } & 0.223 & 0.228 & 0.239 & 0.237 & 0.242 & 0.235 & 0.219 \\
\hline & $(3.85)^{* * *}$ & $(3.77)^{* * *}$ & $(4.01)^{* * *}$ & $(3.98)^{* * *}$ & $(3.44)^{* * *}$ & $(4.32)^{* * *}$ & $(3.83)^{* * *}$ \\
\hline \multirow[t]{2}{*}{ SIZE } & 0.026 & 0.028 & 0.021 & 0.030 & 0.022 & 0.024 & 0.027 \\
\hline & $(2.99)^{* * *}$ & $(2.82)^{* * *}$ & $(2.93)^{* * *}$ & $(3.03)^{* * *}$ & $(2.47)^{* *}$ & $(2.64)^{* * *}$ & $(2.61)^{* * *}$ \\
\hline \multirow[t]{2}{*}{ AGE } & 0.009 & 0.008 & 0.010 & 0.006 & 0.009 & 0.005 & 0.007 \\
\hline & $(0.45)$ & $(0.48)$ & $(0.51)$ & $(0.44)$ & $(0.42)$ & $(0.49)$ & $(0.54)$ \\
\hline Dummy sector & Yes & Yes & Yes & Yes & Yes & Yes & Yes \\
\hline Pseudo R2 & 0.33 & 0.37 & 0.34 & 0.34 & 0.36 & 0.39 & 0.33 \\
\hline Observations & 185 & 185 & 185 & 185 & 185 & 185 & 185 \\
\hline Wald & $(33.98)^{* * *}$ & $(34.25)^{* * *}$ & $(31.93)^{* * *}$ & $(34.59)^{* * *}$ & $(35.02)^{* * *}$ & $(36.85)^{* * *}$ & $(34.81)^{* * *}$ \\
\hline
\end{tabular}

Superscripts ***,**,* indicate statistical significance at 1, 5, and 10 percent, respectively.

Source: Authors' elaboration.

the risk of expropriation, while strengthening the protection of investor rights.

\section{CONCLUSIONS AND DISCUSSION}

Ownership structure has attracted the interest of many researchers in recent decades. However, in Latin America, this analysis has a systemic relevance that is different from developed markets and other emerging countries. Low levels of legal protection for investors have promoted ownership concentration over controlling shareholders and facilitated the creation of various means of expropriation, affecting minority shareholders. As a country governed by French civil law, Chile has not escaped the tendencies of Latin American countries or company behaviors. Over the last few years, various cases of corporate governance malpractices have occurred, affecting minority shareholders and other corporate financers. For example, La Polar in 2011, the case of CMPC and PISA in 2015, SQM in 2015, Masvida en 2017, among others, the effects of which were relevant for various stakeholders.

Therefore, the way in which companies determine corporate dividends and financing policies could have relevant monitoring effects on ownership structure in Chilean companies. According to a vast international literature, there is still no consensus as to whether these policies have a complementary or substitute control effect on ownership structure. Moreover, Chile's entry into the OECD made it necessary to assess how close or how far corporate governance practices were in relation to the recommendations made by this institution. This, together with the controlling role of dividend and financing policies, would allow us to understand how Chilean companies determine ownership structure. 
Our research provides evidence regarding these aspects and their implications can be summarized in three points. First, debt policy exercises a substitute control role (negative effect) in relation to controlling shareholder ownership, and complementary role (positive effect) regarding minority shareholders. This result shows that debt issuance allows for an external control of corporate management, determined by the interests of controlling shareholders, and the protection of minority shareholder rights by complementing monitoring roles. These effects are maintained for a capital structure that does not exceed a debt of $62.25 \%$. Non-linear effects suggest that, for high debt levels, this policy has a positive effect on majority shareholder ownership and a negative effect over minority shareholder ownership. In any case, debt is an effective means that mitigates wealth expropriation from minority shareholders.

Second, dividend policy has a similar effect as debt policy, which means an indirect effect on controlling shareholder ownership and a direct effect over minority shareholder ownership. Since these effects are non-linear, the impact ratio is maintained for dividend rates that do not exceed $89.38 \%$. If we compare this maximum dividend rate with the average dividends of sample companies $(42.74 \%)$, we see that the effects of this policy on ownership structure are vast. In this way, dividend policy is a means that favors the protection of minority shareholder rights and the monitoring of controlling shareholder ownership.

Although financing and dividend policies have a broad control effect on controlling shareholders and support monitoring by minority shareholders, their non-linear effect suggests that their effectiveness decreases. Thus, for a high level of debt (above $62.25 \%$ ) and high dividend rates (greater than $89.38 \%$ ), it is possible to observe a corporate risk transfer, which concentrates ownership in controlling shareholders and expropriates wealth from minority shareholders.

Third, corporate governance practices have significant effects on the ownership structure of Chilean companies. With regard to minority shareholder ownership, the OECD recommendations for better executive functioning, stakeholder relations, and internal control policies have positive effects on ownership. Such effects suggest that the development of good corporate governance practices is a means of encouraging the participation of minority shareholders and mitigating wealth expropriation. This reinforces the internal control roles of investors. Corporate governance practices have mixed effects for controlling shareholder ownership. The negative effects of policies, which improve relationships with stakeholders and compensations to executives, are contrasted with the positive effects of practices that are oriented to board operations and internal control. The latter is an indication that ownership concentration is in opposition to stakeholder rights, who lack decision-making power within firms.

Results show that, for Chilean companies, financing, dividend, and corporate governance policies are an effective means of controlling discretionary ownership concentration, mitigating wealth expropriation, and protecting minority shareholder rights. In this way, such policies constitute a protection mechanism not provided by the country's legal environment, since Chile is governed by French civil law.

A future line of research would be to evaluate these models over time, as a way of visualizing whether Chilean firms indeed adapt their management to the corporate governance recommendations of the OECD or whether the entry of Chile into this organization produced a structural break in governance form. 


\section{REFERENCES}

1. Anderson, R. C., \& Reeb, D. (2004). Board composition: Balancing family influence in S\&P 500 firms. Administrative Science Quarterly, 49(2), 209-237.

2. Ang, J., Cole, R., \& Lin, J. (2000). Agency costs and ownership structure. Journal of Finance, 55 (1), 81-106.

3. Apreda, R. (2000). Corporate governance in Argentina. CEMA Working Papers No. 154, Buenos Aires: Universidad del CEMA.

4. Bae, K., Kang, J., \& Kim, J. (2002). Tunneling or value added? Evidence from mergers by Korean business groups. The Journal of Finance, 57(6), 2695-2740.

5. Baek, J., Kang, J., \& Lee, I. (2006). Business groups and tunneling: Evidence from private securities offerings by Korean Chaebols. The Journal of Finance, 61 (5), 2415-2449.

6. Barclay, M., \& Holderness, C. (1989). Private benefits from control of public corporations. Journal of Financial Economics, 25(2), 371-395.

7. Berle, A., \& Means, G. (1932). The modern corporation and private property. New York: Macmillan.

8. Boeker, W. (1989). Strategic change: The effects of founding and history. The Academy of Management Journal, 32(3), 489-515.

9. Booth, L., Aivazian, V., Demirguc-Kunt, A., \& Maksimovic, V. (2001). Capital structures in developing countries. The Journal of Finance, 56(1), 87-130.

10. Bradford, W., Chen, C., \& Zhu, S. (2013). Cash dividend policy, corporate pyramids, and ownership structure: Evidence from China. International Review of Economics and Finance, 27, 445-464.

11. Brown, L., \& Caylor, M. (2004). Corporate governance study: The correlation between corporate governance and company performance. Institutional Shareholder Services, Inc.

12. Burkart, M., \& Panunzi, F. (2006). Agency conflicts, ownership concentration, and legal shareholder protection. Joumal of Financial Intermediation, 15(1), 1-31.

13. Céspedes, J., González, M., \& Molina, C. (2010). Ownership and capital structure in Latin America. Journal of Business Research, 63(3), 248-254.

14. Chibber, P., \& Majumdar, S. (1999). Foreign ownership and profitability: Property rights, control, and the performance of firms in Indian industry. The Journal of Law and Economics, 42 (1), 209-238.

15. Chong, A., \& Lopez de Silanes, F. (2007). Corporate governance in Latin America. Inter-America Development Bank, Working Paper No. 591.

16. Chu, E., \& Cheah, K. (2004). The determinants of ownership structure in Malasya. Accepted for Presentation at the Fourth Asia Pacific Interdisciplinary Research in Accounting Conference, Singapore, 4-6 July 2004

17. Claessens, S., Djankov, S., \& Lang, L. (2000). The separation of ownership and control in East Asian Corporations. Journal of Financial Economics, 58(1-2), 81-112.

18. De Michele, R. (2002). Corporate Governance: An introduction to the Argentine Case. Working Paper.

19. Demsetz, H., \& Lehn, K. (1985). The structure of corporate ownership: Causes and consequences. Journal of Political Economy, 93(6), 1155-1177.

20. Diamond D. (1984). Financial intermediation and delegated monitoring. The Review of Financial Studies, $51(3), 393-414$. 
21. Du, J., \& Dai, Y. (2005). Ultimate corporate ownership structures and capital structures: evidence from East Asian economies. Corporate Governance: An International Review, 13(1), 60-71.

22. Faccio, M., \& Lang, L. (2001). The separation of ownership and control: An analysis of ultimate ownership in western European countries. Journal of Financial Economics, 65 (3), 365-395.

23. Faccio, M., Lang, L., \& Young, L. (2001). Dividends and expropriation. American Economic Review, 91 (1), 54-78.

24. Fama, E., \& Jensen, M. (1983a). Separation of ownership and control. The Journal of Law and Economics, 26(2), Corporations and Private Property: A Conference Sponsored by the Hoover Institution, 301-325.

25. Fama, E., \& Jensen, M. (1983b). Agency problems and residual claims. Journal of Law and Economics, 26(2), Corporations and Private Property: A Conference Sponsored by the Hoover Institution, 327-349.

26. Hatem, B. (2014). Determinants of ownership structure: A comparison of common and civil law countries. International Business Research, 7(10), 118-124.

27. Hung, H. (1998). A typology of the theories of the roles of governing boards. Corporate Governance, 6(2), 101-111.

28. Jensen, M. (1986). Agency costs of free cash flow, corporate finance, and takeovers. The American Economic Review, 76(2), Papers and Proceedings of the Ninety-Eighth Annual Meeting of the American Economic Association (May, 1986), 323-329.

29. Jensen, M., \& Meckling, W. (1976). Theory of the firm: Managerial behavior, agency costs and ownership structure. Journal of Financial Economics, 3(4), 305-360.

30. Johnson, S., La Porta, R., Lopez de Silanes, F., \& Shleifer, A. (2000). Tunneling. The American Economic Review, $90(2), 22-27$.

31. Klapper, L., \& Love, I. (2004). Corporate governance, investor protection, and performance in emerging markets. Journal of Corporate Finance, 10(5), 703-728.

32. Krivogorsky, V. (2006). Ownership, board structure and performance in continental Europe. The International Journal of Accounting, 41 (2), 176-197.

33. La Porta, R., Lopez de Silanes, F., Andrei, S., \& Vishny, R. (2002). Investor protection and corporate valuation. The Journal of Finance, 57(3), 1147-1170.

34. La Porta, R., Lopez de Silanes, F., \& Shleifer, A. (1999). Corporate ownership around the world. The Journal of Finance, 54(2), 471-517.

35. La Porta, R., Lopez de Silanes, F., Shleifer, A., \& Vishny, R. (1997). Legal determinants of external finance. The Journal of Finance, 52(3), 1131-1150.

36. La Porta, R., Lopez de Silanes, F., Shleifer, A., \& Vishny, R. (1998). Law and finance. Journal of Political Economy, 106(6), 1113-1155.

37. Lang, L., \& Litzenberger, R. (1989). Dividend announcements: Cash Flow Signaling vs. Free Cash Flow Hypothesis? Journal of Financial Economics, 24(1), 181-191.

38. Leal, R., \& De Oliveira, C. (2002). An evaluation of board practices in Brazil. Working Paper, Rio de Janeiro Federal University.

39. Lefort, F., \& Walker, E. (2000). Ownership and capital structure of Chilean conglomerates: Facts and Hypothesis in Chile. Revista Abante, 3(1), 3-27. 
40. Lefort, F. (2005). Ownership structure and corporate governance in Latin America. Revista Abante, 8(1), $55-84$

41. Lefort, F., \& Walker, E. (2007). Do markets penalize agency conflicts between controlling and minority shareholders? Evidence from Chile. The Developing Economies, 45(3), 283-314.

42. Leland, H., \& Pyle, D. (1977). Information asymmetries, financial structure and financial intermediation. The Journal of Finance, 32(2), 371-387.

43. Lins, K. (2003). Equity ownership and firm value in emerging markets. The Journal of Financial and Quantitative Analysis, 38(1), 159-184.

44. López-Iturriaga, F., \& Lima, V. (2014). Do leverage dividend payout, and ownership concentration influence firms' value creation? An analysis of Brazilian firms. Emerging Markets Finance and Trade, 46(3), 80-94.

45. Mak, Y., \& Li, Y. (2001). Determinants of corporate ownership and board structure: evidence from Singapore. Journal of Corporate Finance, 7(1), 235-256.

46. Mancinelli, L., \& Aydin, O. (2006). Ownership structure and dividend policy: Evidence from Italian firms. The European Journal of Finance, 12(3), 265-282.

47. Maquieira, C., \& Danús, M. (1998). Costos de agencia y costos de transacción como determinantes de la tasa de pago de dividendos en Chile. Estudios de Administración, 5(2), 49-81.

48. Maquieira, C., \& Moncayo, I. (2004). Costos de agencia y costos de transacción como determinantes de la tasa de pago de dividendos en Chile: Extensión. Estudios de Administración, 11(2), 1-26.

49. Morales, M., Meléndez, M., \& Ramírez, V. (2013). Determinants of ownership concentration in the Chilean stock market. Cepal Review, 110, 175-188.

50. Mori, N., \& Ikeda, N. (2015). Majority support of shareholders, monitoring incentive, and dividend policy. Journal of Corporate Finance, 30, 1-10.

51. Nenova, T. (2003). The value of corporate voting rights and control: A cross-country analysis. Journal of Financial Economics, 68(3), 325-351.

52. Pedersen, T., \& Thomsen, S. (1997). European patterns of corporate ownership: A Twelve-country study. Journal of International Business Studies, 4, 759-778.

53. Pindado, J., \& De La Torre, C. (2006). The role of investment, financing and dividend decisions in explaining corporate ownership structure: Empirical evidence from Spain. European Financial Management, 12(5), 661-687.

54. Pindado, J., Requejo, I., \& De la Torre, C. (2012). Do family firms use dividend policy as a governance mechanism? Evidence from the Euro zone. Corporate governance. An International Review, 20(5), 413-431.

55. Ramli, N. (2010). Ownership structure and dividend policy: Evidence from Malaysian companies. International Review of Business Research Papers, 6(1), 170-180.

56. Renders, A., \& Gaeremynck, A. (2012). Corporate governance, principal-principal agency conflicts, and firm value in European listed companies. Corporate Governance: An international review, 20(2), 125-143.

57. Roy, A. (2015). Dividend policy ownership structure and corporate governance: An empirical analysis of Indian firms. Indian Journal of Corporate Governance, 8(1), 1-33.

58. Rozeff, M. (1982). Growth, beta and agency costs as determinants of dividend payout ratios. The Journal of Financial Research, 5(3), 249-259. 
59. Santiago, M., \& Brown, C. (2007). Ownership structure and minority rights: A Latin American view. Journal of Economics and Business, 59(5), 430-442.

60. Setia-Atmaja, L. Y. (2009). Governance mechanisms and firm value: The impact of ownership concentration and dividends. Corporate Governance: An International Review, 17(6), 694-709.

61. Shleifer, A., \& Vishny, R. (1997). A survey of corporate governance. The Journal of Finance, 52 (2), 737-775.

62. Silva, F., Majluf, N., \& Paredes, R. (2006). Family ties, interlocking directors and performance of business groups in emerging countries: The case of Chile. Journal of Business Research, 59(3), 315-321.

63. Thomsen, S., \& Pedersen, T. (1996). Nationality and ownership structures: The 100 largest companies in six European nations. Management International Review, 36(2), 149-166.

64. Yoon, P., \& Starks, L. (1995). Signaling, Investment Opportunities and Dividend Announcements. The Review of Financial Studies, 8(4), 995-1018.

65. Weiss, C., \& A. Richter (2010), Determinants of ownership concentration: the importance of firm-, industry- and country-level factors, European Business School Research Paper, No. 10-05, Wiesbaden, EBS Business School.

66. Zahra, S., \& Pearce, J. (1989). Boards of directors and corporate financial performance: A review and integrative model. Journal of Management, 15(2), 291-334. 